\title{
Karakter Agronomi dan Kadar Sinensetin Beberapa Aksesi Tanaman Kumis Kucing (Orthosiphon stamineus)
}

\author{
Agronomy Character and Sinensetin Content of Several Java's Tea Plant Accession \\ (Orthosiphon stamineus)
}

\author{
Shalati Febjislamii $^{1}$, Maya Melati ${ }^{2}$, Ani Kurniawati ${ }^{2 *}$, dan Yudiwanti Wahyu ${ }^{2}$
}

Diterima 23 Juli 2017/Disetujui 15 Oktober 2018

\begin{abstract}
Java's tea plants have efficacy to treat diabetes. Sinensetin is a chemical compound in Java's tea that acts as diabetes medicine. The experiment objective was to study diversity of agronomy characters and sinensetin content of ex situ collections of Java's tea from West, Central, and East Java regions. Java's tea was harvested when population has flowering about $70 \%$ and tested sinensetin content on leaf part. The experiment was conducted with a completely randomized block design with 18 accessions and one control (purple flower accession). The result of study showed that there were significant differences in the accumulation of height plant increase while 8 weeks after planting, secondary branches and secondary branches internode number; leaf length, width and area index; average stems and leaf dry weight per $4.41 \mathrm{~m}^{2}$ and sinensetin levels among some accessions. Banyumas 1, Sumbersari and Kraksaan accessions have agronomy and production characters except for sinensetin levels were better than control (Leaf sinensetin levels based on leaf dry weight increased from low to medium but decreased in high category) Based on comparison between accession and leaf dry weight category, purple flower accession has higher sinensetin levels $(0.043 \%)$ than another accession, but only reaches $43 \%$ of Indonesian Herbal Pharmacopoeia minimum standard (There were no significant differences in sinensetin accession production tested either by comparison of accession or accession categories).
\end{abstract}

Keywords: ex situ, flower, Java's tea, Orthosiphon aristatus, sinensetin

\section{ABSTRAK}

Tanaman kumis kucing berkhasiat untuk mengobati penyakit diabetes. Sinensetin merupakan senyawa kimia pada kumis kucing yang berperan sebagai obat diabetes. Tujuan penelitian adalah untuk mempelajari keragaman karakter agronomi dan kandungan sinensetin tanaman kumis kucing hasil koleksi ex situ dari daerah Jawa Barat, Jawa Tengah dan Jawa Timur. Tanaman kumis kucing dipanen saat populasi berbunga sekitar $70 \%$ dan diuji kandungan sinensetin pada daunnya. Rancangan percobaan yang digunakan adalah rancangan kelompok lengkap teracak dengan perlakuan 18 aksesi dan satu pembanding (koleksi ungu). Hasil penelitian menunjukkan terdapat perbedaan yang signifikan pada akumulasi pertambahan tinggi selama 8 MST, jumlah cabang sekunder dan ruas cabang sekunder; panjang, lebar dan indeks luas daun; rata-rata bobot kering batang dan daun per 4.41 $\mathrm{m}^{2}$ serta kadar sinensetin antar aksesi yang diuji. Aksesi Banyumas 1, Sumbersari dan Kraksaan memiliki karakter agronomi dan produksi yang lebih baik daripada kontrol kecuali kadar sinensetinnya. Kadar sinensetin daun berdasarkan kategori bobot kering daun mengalami peningkatan dari kategori rendah ke menengah namun menurun pada kategori tinggi. Berdasarkan perbandingan antar aksesi maupun kategori bobot kering daun, kontrol memiliki kadar sinensetin $(0.043 \%)$ yang lebih baik, namun hanya mencapai $43 \%$ dari standar minimum kandungan kimia simplisia (kadar sinensetin) yang ditetapkan oleh Farmakope Herbal Indonesia. Tidak terdapat perbedaan yang signifikan pada produksi sinensetin aksesi yang diuji baik berdasarkan perbandingan aksesi maupun kategori aksesi.

Kata kunci: bunga, ex situ, kumis kucing, Orthosiphon aristatus, sinensetin

\footnotetext{
${ }^{1}$ Mahasiswa Program Studi Agronomi dan Hortikultura, Sekolah Pascasarjana, Institut Pertanian Bogor

${ }^{2}$ Staf Pengajar Departemen Agronomi dan Hortikultura, Fakultas Pertanian, Institut Pertanian Bogor

Jl. Meranti, Kampus IPB Darmaga, Bogor 16680, Telp/Fax (0251) 8629353, Indonesia

E-mail: ani_kurniawati@apps.ipb.ac.id (*Penulis korespondensi)
} 


\section{PENDAHULUAN}

Tanaman kumis kucing berkhasiat untuk mengobati beberapa penyakit salah satu diantaranya adalah diabetes. Daun tanaman kumis kucing diperkenalkan ke Eropa dan Jepang sebagai teh kesehatan yang biasanya dikenal dengan sebutan "Java Tea" (Ameer $e t$ al., 2012). Dokter praktik di daerah Jawa dan Bali sebagian besar menggunakan jamu sebagai pengobatan komplementer dan alternatif selain pengobatan konvensional. Tanaman kumis kucing merupakan salah satu dari bahan jamu yang banyak digunakan (Delima et al., 2012).

Tezuka et al. (2000); Hossain dan Rahman (2011), menyatakan enam senyawa flavonoid yang diisolasi dari daun $O$. stamineus berdasarkan strukturnya dikenal sebagai eupatorin, sinensetin, salvigenin, 5-hydroxy6,7,3', '4'-tetramethoxyflavone, 6-hydroxy$5,7,4$ '-trimethoxyflavone dan 5,6,7,3' tetramethoxy-4'-hydroxy-8-C-prenylflavone. Sinensetin termasuk salah satu senyawa yang tidak menunjukkan toksisitas. Beberapa penelitian pada tikus (Mohamed et al., 2011; Indariani et al., 2014), menunjukkan senyawa flavonoid (sinensetin) hasil ekstrak daun $O$. stamineus dan $O$. aristatus bersifat antihiperglikemik. Utiger (2014) menyatakan hiperglikemik terjadi ketika konsentrasi gula darah meningkat sehingga berada diatas kisaran normal dan kondisi ini didiagnosis sebagai diabetes mellitus. Menurut Chisholm-Burn et al. (2008) kondisi ini dapat diatasi dengan menghambat aktifitas $\alpha$-glukosidase. Penyerapan karbohidrat di usus halus ditunda oleh penghambat $\alpha$-glukosidase sehingga mencegah peningkatan glukosa dalam darah setelah makan.

Mohamed et al. (2012) menyatakan komposisi fitokimia hasil uji HPLC ekstrak etanol $50 \%$ dari $O$. stamineus terdiri atas 3 'hydroxy-5,6,7,4'-tetramethoxyflavone $(1.015 \pm 0.001 \%)$, sinensetin $(3.764 \pm 0.019 \%)$ dan eupatorin $(3.032 \pm 0.025 \%)$. Pengujian daya hambat terhadap $\alpha$-glukosidase secara in vitro menggunakan ekstrak etanol $50 \%$ dari $O$. stamineus, sinensetin (hasil isolasi ekstrak etanol $50 \%$ dari $O$. stamineus) dan akarbose (sebagai kontrol positif) menunjukkan daya hambat maksimal (81.4\%) baru dapat dicapai dengan penggunaan $62.5 \mathrm{mg} \mathrm{mL}^{-1}$ ekstrak etanol $50 \%$ dari O. stamineus. Sinensetin, hanya dengan penggunaan sebesar $2.5 \mathrm{mg} \mathrm{mL}^{-1}$ menunjukkan persentase daya hambat yang kuat sebesar $89 \%$, berbeda dengan akarbose pada dosis yang sama menghasilkan daya hambat lebih rendah $(65 \%)$. Terlihat bahwa ekstrak etanol 50\% dari O. stamineus memiliki potensi yang masih rendah dalam menghambat $\alpha$-glukosidase dibandingkan dengan akarbose dan sinensetin.

Meskipun potensi ekstrak $O$. stamineus masih rendah dalam menghambat $\alpha$ glukosidase, Mohamed et al. (2012) menyatakan ekstrak etanol $50 \%$ dari $O$. stamineus memiliki aktivitas daya hambat yang dapat diterima dan sama dengan sinensetin terhadap $\alpha$-glukosidase. Daya hambat terhadap $\alpha$-glukosidase berpotensi sebagai terapi efektif terhadap hiperglikemia post-prandial yang berkaitan dengan penyakit diabetes tipe 2 . Efek sampingnya juga lebih sedikit, dibandingkan penggunaan inhibitor $\alpha$-glukosidase yang ampuh seperti akarbose, oleh sebab itu, upaya perlu dilakukan untuk meningkatkan potensi tanaman kumis kucing sebagai obat diabetes melalui penelitian agar didapat informasi kumis kucing yang memiliki kandungan sinensetin dan aktivitas yang tinggi.

Salah satu upaya untuk meningkat potensi tanaman kumis kucing adalah melalui identifikasi koleksi ex situ kumis kucing yang tumbuh di berbagai kondisi agroekosistem. Menurut Syukur (2008) dan Sembiring et al. (2012), sentra penanaman kumis kucing di Indonesia banyak terdapat di pulau Jawa. Daerah produksi kumis kucing di Indonesia adalah Jawa Barat (Bogor dan Sukabumi), Aceh, Sumatera Barat, Sumatera Timur, dan Sulawesi Utara. Wahid (1998), Rahardjo dan Rosita (2003) menyatakan kondisi agroekosistem mempengaruhi potensi genetik tanaman obat sehingga mempengaruhi keragaman, kuantitas dan kualitas bahan baku tanaman obat. Maka dari itu perlu dilakukan studi untuk melihat keragaman karakter agronomi tanaman kumis kucing dan kandungan sinensetinnya. Penelitian ini bertujuan untuk mengetahui keragaman karakter agronomi tanaman kumis kucing dan kandungan sinensetin beberapa aksesi tanaman kumis kucing hasil koleksi ex situ dari daerah Jawa Barat, Jawa Tengah, dan Jawa Timur 


\section{BAHAN DAN METODE}

Penelitian dilaksanakan di Kebun Percobaan Sawah Baru, Kampus IPB Darmaga, Bogor, dari bulan Maret sampai September 2015. Analisis kandungan bahan bioaktif (sinensetin) dilaksanakan di laboratorium Pusat Studi Biofarmaka Tropika (PSBT) Taman Kencana, Bogor pada tanggal 8 sampai 12 Agustus 2016.

Bahan-bahan yang digunakan yaitu setek batang kumis kucing dari 18 aksesi hasil koleksi ex situ dari daerah Jawa Tengah, Jawa Timur dan 1 aksesi koleksi Kebun Percobaan Manoko Lembang. Bahan untuk pengujian sinensetin adalah simplisia dari dua aksesi yang masing-masing mewakili kategori bobot kering per tanaman rendah (4.33-7.11 g), menengah (9.34-11.08 g) dan tinggi (12.22-15.66 g) serta satu pembanding/kontrol yaitu aksesi berbunga ungu. Alat-alat yang digunakan adalah alat budidaya tanaman, timbangan, oven, alat HPLC merk Shimadzu-LC System (HPLC Column: Merck Millipore LiChroCART® C$18(5 \mu \mathrm{m})$ 125-4), alat-alat laboratorium dan alat-alat lain yang mendukung penelitian.

Penelitian menggunakan rancangan kelompok lengkap teracak (RKLT) satu faktor yaitu jumlah aksesi sebanyak 19 aksesi. Perlakuan diulang 3 kali sehingga terdapat 57 satuan percobaan dengan 10 tanaman contoh per satuan percobaan. Bahan tanam berupa stek kumis kucing 2 buku ditanam pada tray semai menggunakan media campuran top soil dan pupuk kandang (1:1). Pembibitan dilakukan di tempat yang ternaungi selama 4 minggu.

Persiapan lahan dilakukan 2-3 minggu sebelum pindah tanam. Bedengan dibuat berukuran $2.1 \mathrm{~m} \times 2.1 \mathrm{~m} \times 0.25 \mathrm{~m}$ dengan jarak antar bedengan $0.3 \mathrm{~m}$. Lahan diberi kapur dengan dosis 1 ton ha $^{-1}$ serta pupuk dasar (pupuk kandang sapi) dengan dosis 20 ton $\mathrm{ha}^{-1}$. Pupuk dasar diaplikasikan seminggu sebelum pindah tanam dan langsung pada lubang tanam $30 \mathrm{~cm}$ x $30 \mathrm{~cm}$ dengan kedalaman $10-15 \mathrm{~cm}$. Total populasi dalam satu bedeng adalah 49 tanaman sehingga total populasi per aksesi adalah 147 tanaman.

Kegiatan pemeliharaan meliputi penyulaman (1-2 MST), pengendalian hama dan penyakit, pengendalian gulma, pembumbunan dan penyiraman (1-2 kali sehari atau tergantung kondisi cuaca). Panen dilakukan saat tanaman telah berbunga dan mekar $75 \%$ dengan cara memangkas tanaman $15 \mathrm{~cm}$ dari permukaan tanah. Hasil panen dibersihkan dari kotoran, hama atau penyakit dan dipisahkan menurut bagiannya (batang, daun dan bunga). Pengeringan dilakukan dengan oven dengan suhu $50{ }^{\circ} \mathrm{C}$ selama 24 jam hingga kadar airnya mencapai $\pm 10 \%$ (Sujipto et al., 2009).

Pengamatan meliputi karakter agronomi, produktivitas dan kandungan bahan bioaktif (sinensetin). Karakter agronomi yang diamati adalah pertambahan tinggi tanaman $(\mathrm{cm})$, jumlah cabang sekunder dan ruas cabang sekunder, panjang dan lebar daun $(\mathrm{cm})$ serta indeks luas daun (ILD). Peubah pengamatan produktivitas adalah bobot kering daun dan batang (per $4.41 \mathrm{~m}^{2}$ ). Peubah kandungan bioaktif yaitu kadar sinensetin pada daun. Tahap pengujian kadar sinensetin mengikuti prosedur yang dilakukan oleh Pusat Studi Biofarmaka Tropika (PSBT) dengan alat Highperformance Liquid Chromatography (HPLC). Metode pengujiannya yaitu mengekstrak simplisia kumis kucing yang sudah dikeringkan dengan cara simplisia kumis kucing dihaluskan sehingga berbentuk tepung. Simplisia yang telah dihaluskan diambil sebanyak $1 \mathrm{~g}$ dan dilarutkan menggunakan methanol $100 \mathrm{ml}$. Selanjutnya suspensi dikocok dengan shaker selama 4 jam dan kemudian disaring. Hasil saringan dievaporasi hingga tersisa $5 \mathrm{ml}$. Hasil evaporasi berupa ekstrak dilarutkan menjadi 10 ml dengan pelarut campuran $\mathrm{NaOH}$ air (6:4), saring $0.45 \mu \mathrm{m}$ lalu diinjeksikan kedalam HPLC untuk dianalisis kadar sinensetinnya (Yam et al., 2011).

Data hasil pengamatan dianalisis menggunakan analisis ragam (Uji F). Hasil yang berpengaruh nyata dilanjutkan dengan uji Dunnett pada taraf $5 \%$.

\section{HASIL DAN PEMBAHASAN}

\section{Akumulasi Pertambahan Tinggi}

Akumulasi pertambahan tinggi tanaman kumis kucing pada Gambar 1 menunjukkan terdapat $22 \%$ aksesi yang memiliki pertambahan tinggi yang lebih tinggi dari pada kontrol. Kisaran perbedaan pertambahan tinggi aksesi lainnya dengan aksesi kontrol adalah $-25.97-95.08 \%$. 


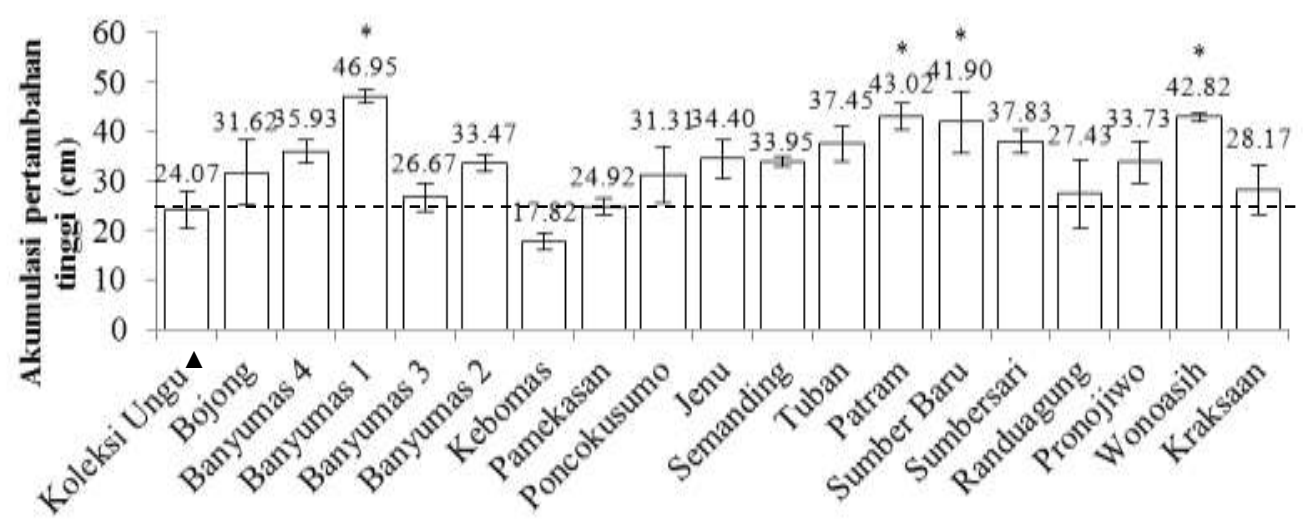

Aksesi

Gambar 1. Rata-rata akumulasi pertambahan tinggi tanaman kumis kucing saat 8 MST. Tanda * di atas tiap balok data menunjukkan perbedaan yang nyata dengan kontrol (Koleksi Ungu ${ }^{\Delta}$ ) pada Uji Dunnett $(\alpha=0.05)$.

Pertambahan tinggi sangat berpengaruh terhadap tinggi tanaman yang sangat menentukan produksi daun kumis kucing yang bisa dipanen. Pemanenan kumis kucing umumnya dengan cara pemangkasan dengan ketinggian tertentu dari atas permukaan tanah. Semakin tinggi tanaman maka makin banyak pula daun pada bagian batang yang dapat dipanen. Demura dan Zheng (2010) menyatakan peningkatan pada pertumbuhan vegetatif tanaman akan menghasilkan produksi biomassa tanaman yang lebih tinggi. Tanaman biofuel seperti rumput gajah (miscanthus dan switchgrass) serta hybrid poplar (pohon poplar hibrida) memiliki produksi biomassa tanaman yang lebih tinggi karena peningkatan pada pertumbuhan vegetatifnya.

\section{Rata-rata Jumlah Cabang Sekunder dan Ruas Cabang Sekunder}

Gambar 2 menunjukkan rata-rata jumlah cabang sekunder dan ruas cabang sekunder antara kontrol dengan aksesi lainnya. Sekitar $72 \%$ aksesi memiliki jumlah cabang sekunder yang lebih besar daripada kontrol. Perbedaan besaran jumlah cabang sekunder aksesi lainnya dengan kontrol ungu adalah -7.8-41.0\%, sedangkan pada jumlah ruas cabang sekunder semua aksesi lainnya, memiliki perbedaan jumlah ruas yang lebih besar daripada kontrol sebesar $4.3-54.1 \%$.
Terdapat 3 aksesi dengan perbedaan jumlah cabang di atas 39\% atau minimal memiliki 13.2 cabang merupakan aksesi yang lebih baik daripada kontrol. Aksesi Pamekasan memiliki jumlah cabang sekunder jauh lebih rendah daripada kontrol, sedangkan pada jumlah ruas, terdapat 8 aksesi yang memiliki perbedaan jumlah ruas yang lebih baik daripada kontrol. Aksesi-aksesi tersebut memiliki perbedaan jumlah ruas di atas $28 \%$ atau minimal memiliki 8.9 ruas.

Pertambahan tinggi tanaman, jumlah cabang sekunder dan ruas pada cabang sekunder jadi penentu jumlah daun dan produksi daun tanaman kumis kucing. Tanaman dengan pertambahan tinggi terbesar, jumlah cabang sekunder dan ruas cabang sekunder terbanyak memiliki peluang memiliki jumlah buku terbanyak.

Salah satu karakter dari tanaman kumis kucing adalah daunnya tumbuh secara berpasangan pada setiap buku. Semakin banyak jumlah bukunya maka semakin banyak jumlah daunnya. Sesuai dengan yang disampaikan Samanhudi et al. (2010); Rahmania dan Kurniawati (2014) semakin banyak jumlah buku, semakin banyak pula jumlah tunasnya karena pada buku tersebut terdapat mata tunas yang akan tumbuh menjadi tunas baru. Jumlah daun yang dihasilkan kumis kucing tergantung pada jumlah buku dan jumlah cabang. 

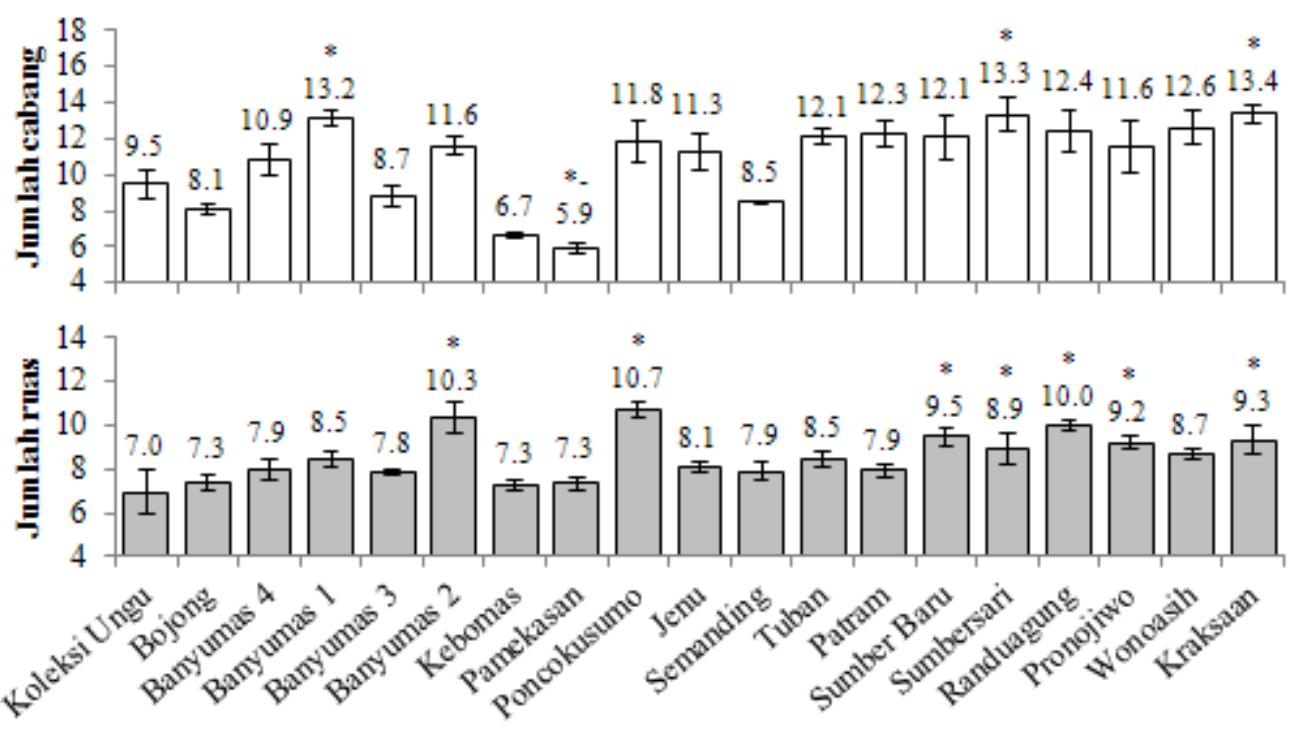

Aksesi

Gambar 2. Rata-rata jumlah cabang sekunder (a) dan ruas cabang sekunder (b). Tanda * di atas tiap balok data menunjukkan perbedaan yang nyata dengan kontrol (Koleksi Ungu ${ }^{\boldsymbol{\Lambda}}$ ) pada Uji Dunnett $(\alpha=0.05)$.

\section{Rata-rata Panjang, Lebar dan Indeks Luas Daun}

Gambar 3 menunjukkan rata-rata panjang daun, lebar daun dan indeks luas daun antara kontrol dengan aksesi lainnya. Secara umum aksesi lainnya memiliki panjang daun, lebar daun dan indeks luas daun yang lebih besar daripada kontrol. Pengecualian pada indeks luas daun, terdapat satu aksesi yaitu Aksesi Pamekasan memiliki nilai yang lebih rendah daripada kontrol. Nilai perbedaan panjang daun, lebar daun dan indeks luas daun aksesi lainnya dengan kontrol berturut-turut adalah 7.5-52\%, 11-66\% dan -6.5-156\%.

Aksesi dengan panjang daun 23\% lebih besar dari kontrol atau memiliki panjang daun minimal $5.5 \mathrm{~cm}$ (12 aksesi), merupakan aksesi dengan panjang daun yang lebih baik daripada koleksi ungu. Sebanyak 16 aksesi dengan lebar daun minimal $3.04 \mathrm{~cm}$ atau 35\% lebih besar dari kontrol memiliki lebar daun yang lebih baik daripada kontrol. Terdapat 10 aksesi dengan perbedaan indeks luas daun mimimal $115 \%$ dari kontrol atau memiliki indeks luas daun minimal 2.17 lebih baik indeks luas daunnya daripada kontrol.

Jika dilihat dari proporsinya, lebih banyak aksesi yang memiliki lebar daun yang lebih besar daripada kontrol, diikuti oleh panjang daun dan indeks luas daun. Berdasarkan panjang, lebar dan indeks luas daun terdapat 7 aksesi yang lebih baik dari pada kontrol. Aksesi-aksesi tersebut yaitu Aksesi Bojong, Banyumas 1, Banyumas 3, Semading, Patram, Sumbersari, Randuagung dan Pronojiwo.

Panjang dan lebar daun menentukan luas daun dalam satu daun. Semakin panjang dan lebar daun maka semakin luas daun tersebut. Daun yang luas dapat menjadi salah satu faktor penentu kuantitas produksi tanaman kumis kucing. Namun kondisi ini harus didukung juga oleh jumlah daun. Pada penelitian ini tidak dilakukan pengamatan jumlah daun tapi dilakukan pengamatan indeks luas daun yang diharapkan menjadi proyeksi dari kuantitas produksi tiap aksesi kumis kucing yang diuji. Menurut Samanhudi et al. (2010) luas daun berkolerasi positif dengan bobot kering total tanaman. Pada uji korelasi terlihat bahwa luas daun menunjukkan adanya pertambahan ukuran daun yang akan diikuti pertambahan berat daun. Berat daun akan mempengaruhi berat kering total tanaman. Setyowati et al. (2014) menyatakan produktivitas tanaman padi dapat ditentukan oleh perkembangan luas daun diawal fase pertumbuhan. Leaf Area Index (LAI) saat 30 HST berkorelasi positif dengan hasil gabah. 


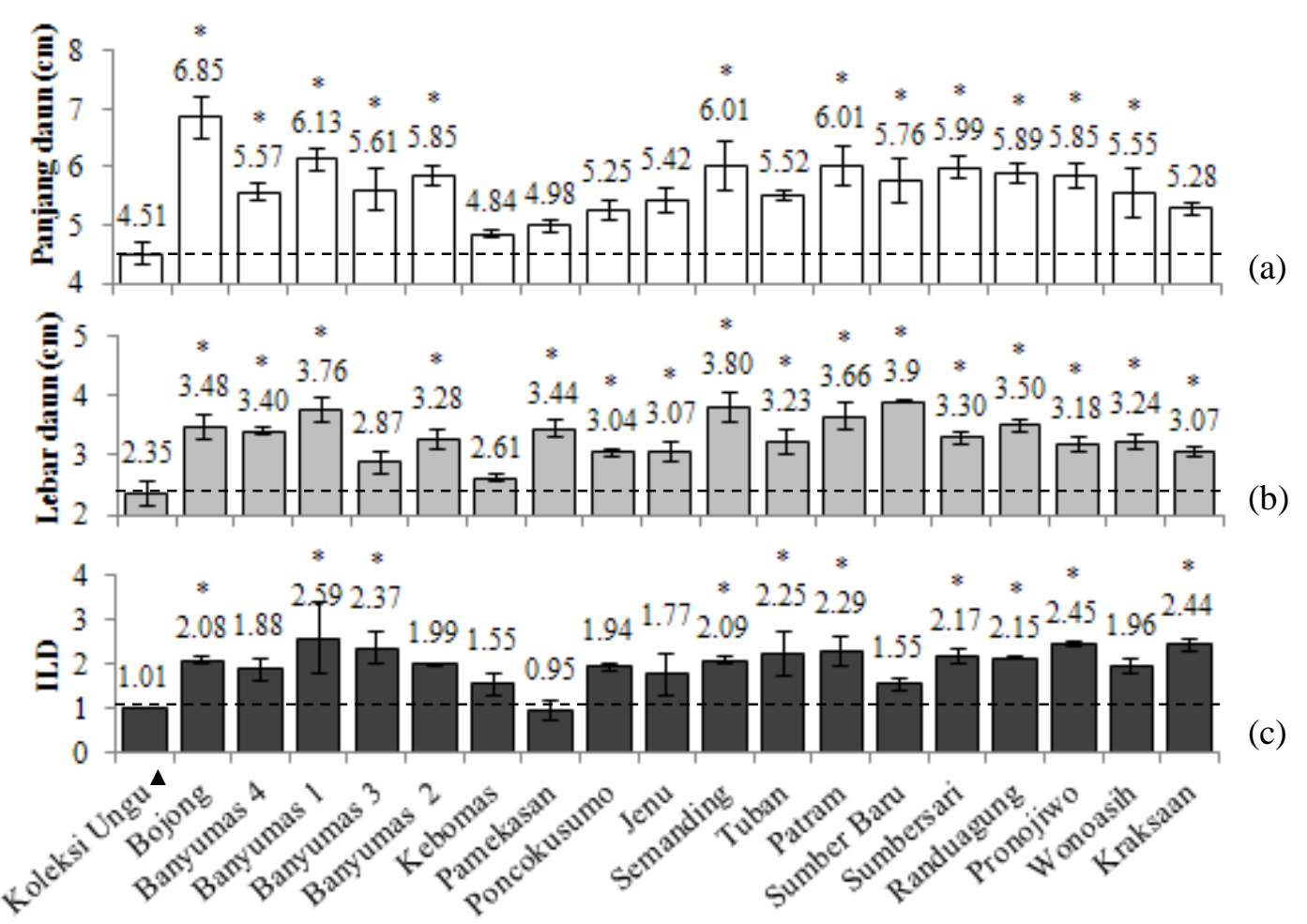

\section{Aksesi}

Gambar 3. Rata-rata panjang (a) dan lebar daun (b) ke-5 dari pucuk dan indeks luas daun (c). Tanda $*$ di atas tiap balok data menunjukkan perbedaan yang nyata dengan kontrol

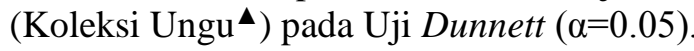

\section{Rata-rata Bobot Bobot Kering Daun dan Batang per $4.41 \mathrm{~m}^{2}$}

Rata-rata bobot kering daun dan batang per $4.41 \mathrm{~m}^{2}$ tiap aksesi ditampilkan pada Gambar 4. Secara umum hampir semua aksesi lainnya memiliki perbedaan bobot kering batang dan daun yang lebih besar daripada kontrol.

Aksesi Pamekasan, sebagai pengecualian, memiliki perbedaan yang lebih rendah dari pada kontrol. Perbedaan bobot kering daun dan batang aksesi lainnya berturut-turut dengan kontrol adalah -19-212.3\% dan -33-187.5\%. Terdapat 10 aksesi yang lebih baik bobot kering daunnya dengan perbedaan bobot kering daun diatas $94 \%$ dari kontrol. Kemudian hanya terdapat dua aksesi yang memiliki bobot kering batang yang lebih baik daripada kontrol yaitu aksesi Banyumas 1 dan Sumbersari yang memiliki perbedaan bobot kering batang diatas $155 \%$ dari kontrol. pengaruh peningkatan bobot kering batang terhadap peningkatan bobot kering daun secara tidak langsung dipengaruhi oleh jumlah cabang sekunder. Peningkatan jumlah cabang sekunder berpengaruh terhadap jumlah buku dan daun yang sangat berkaitan dengan produksi daun tanaman kumis kucing.

\section{Kadar Sinensetin Daun}

Sampel kumis kucing yang diuji kandungan sinensetinnya dikelompokkan menjadi 3 kelompok berdasarkan produksi bobot kering daun per tanaman yaitu rendah, sedang dan tinggi. Aksesi kumis kucing yang memiliki berat kering daun 12.22-15.66 g (10 aksesi) dimasukkan dalam kelompok tinggi. Kelompok sedang terdiri dari aksesi yang memiliki berat kering daun 9.34-11.08 g (6 aksesi). Kemudian aksesi dengan berat kering 4.33-7.11 g (3 aksesi) dimasukkan ke dalam kelompok rendah. Dua aksesi yang dianggap paling mewakili sebagai sampel diambil dari setiap kelompok. Aksesi Sumbersari dan Kraksaan mewakili kelompok tinggi. Aksesi Banyumas 4 dan Jenu mewakili kelompok sedang, kemudian kelompok rendah diwakili oleh aksesi Kebomas. Masing-masing aksesi yang diuji kadar sinensetinnya juga dilihat 
perbandingannya dengan kontrol tanpa pengelompokan berdasarkan kategori bobot kering daun.

Hasil pengujian sinensetin menunjukkan kadar sinensetin daun meningkat dari bobot kering daun kategori rendah hingga kategori menengah. Kemudian menurun pada kategori tinggi. Terdapat perbedaan antara kadar sinensetin daun dan bobot kering daun per 4.41 $\mathrm{m}^{2}$ ketiga kategori aksesi dengan kontrol. Kadar sinensetin daun ketiga kategori aksesi lebih rendah daripada kontrol, sedangkan bobot kering daun aksesi yang termasuk kategori tinggi lebih baik daripada kontrol (Tabel 1).

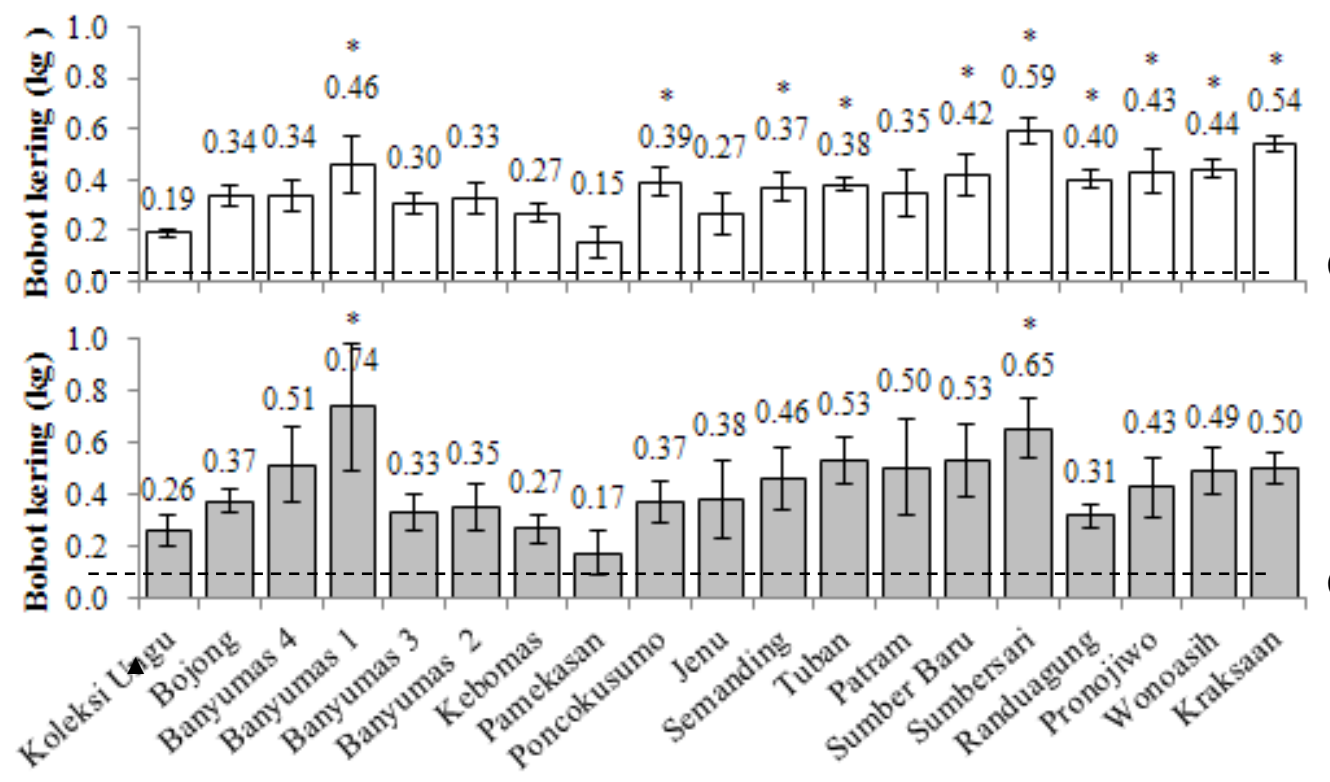

Gambar 4. Rata-rata bobot kering daun (a) dan batang (b) per $4.41 \mathrm{~m}^{2}$. Tanda $*$ di atas tiap balok data menunjukkan perbedaan yang nyata dengan kontrol (Koleksi Ungu ${ }^{\wedge}$ ) pada Uji Dunnett $(\alpha=0.05)$.

Tabel 1. Kadar sinensetin daun dan produksi sinensetin berdasarkan kategori bobot kering daun dan aksesi

\begin{tabular}{|c|c|c|c|c|c|}
\hline \multirow{2}{*}{$\begin{array}{c}\text { Kategori } \\
\text { Bobot } \\
\text { Tanaman }\end{array}$} & \multirow{2}{*}{ Aksesi } & \multicolumn{2}{|c|}{ Sinensetin $^{\mathrm{a}}$} & \multirow{2}{*}{$\begin{array}{c}\text { Berat Kering } \\
\text { Daun }^{\mathrm{a}}\end{array}$} & \multirow{2}{*}{$\begin{array}{c}\text { Produksi } \\
\text { Sinensetin } \\
\mathrm{g} / 4.41 \mathrm{~m}^{2}\end{array}$} \\
\hline & & $\mathrm{mg} / \mathrm{g} \mathrm{BK}$ & $\%$ & & \\
\hline Kontrol & Koleksi Ungu & 0.43 & 0.043 & 190.30 & 7.86 \\
\hline \multirow[t]{3}{*}{ Rendah } & Kebomas & $0.22 *$ & $0.022 *$ & 268.32 & 5.54 \\
\hline & Pamekasan & $0.17 *$ & $0.017 *$ & 154.10 & 3.44 \\
\hline & Rata-rata & $0.20 *$ & $0.020^{*}$ & 211.21 & 4.49 \\
\hline \multirow[t]{3}{*}{ Sedang } & Banyumas 4 & 0.30 & 0.030 & $339.58^{*}$ & 10.61 \\
\hline & Jenu & 0.27 & 0.027 & 265.16 & 7.53 \\
\hline & Rata-rata & $0.29 *$ & $0.029 *$ & 302.37 & 9.07 \\
\hline \multirow[t]{3}{*}{ Tinggi } & Sumbersari & $0.15^{*}$ & $0.015^{*}$ & 594.23* & 8.73 \\
\hline & Kraksaan & $0.13^{*}$ & $0.013 *$ & $543.84 *$ & 7.42 \\
\hline & Rata-rata & $0.14 *$ & $0.014 *$ & $569.03 *$ & 8.08 \\
\hline
\end{tabular}

Keterangan: a Angka-angka pada kolom yang sama yang diikuti oleh tanda $*$ menunjukkan perbedaan yang nyata dengan kontrol (Koleksi Ungu) pada Uji Dunnett $(\alpha=5 \%)$. 
Tabel 2. Kadar sinensetin aksesi tanaman kumis kucing berdasarkan warna bunga dan hasil uji korelasi

\begin{tabular}{|c|c|c|c|c|c|c|}
\hline \multirow[t]{2}{*}{ No } & \multirow[t]{2}{*}{ Aksesi } & \multirow{2}{*}{$\begin{array}{l}\text { Warna } \\
\text { Bunga }\end{array}$} & \multirow{2}{*}{$\begin{array}{c}\text { Skor Warna } \\
\text { Bunga }^{\mathrm{a}}\end{array}$} & Sinensetin & $\begin{array}{c}\text { Rata-rata } \\
\text { Sinensetin }\end{array}$ & \multirow{2}{*}{$\begin{array}{c}\text { Nilai } \\
\text { Korelasi }\end{array}$} \\
\hline & & & & $\%$ & $\%$ & \\
\hline 1 & Kontrol & Ungu & 4 & 0.043 & 0.043 & \multirow{7}{*}{$\begin{array}{c}\text { Pearson } \\
\text { correlation: } \\
0.805 \\
\text { P-value: } \\
0.404\end{array}$} \\
\hline 2 & Kebomas & Intermediate & 3 & 0.022 & 0.022 & \\
\hline 3 & Pamekasan & Putih & 1 & 0.017 & 0.020 & \\
\hline 4 & Banyumas 4 & Putih & 1 & 0.030 & 0.020 & \\
\hline 5 & Jenu & Putih & 1 & 0.027 & 0.020 & \\
\hline 6 & Sumbersari & Putih & 1 & 0.015 & 0.020 & \\
\hline 7 & Kraksaan & Putih & 1 & 0.013 & 0.020 & \\
\hline
\end{tabular}

Aksesi yang termasuk kategori sedang dan tinggi memiliki produksi sinensetin per $4.41 \mathrm{~m}^{2}$ yang lebih tinggi dari kontrol. Hal ini disebabkan oleh bobot kering yang lebih tinggi pada aksesi kategori sedang dan tinggi dibandingkan kontrol. Meskipun berdasarkan pengujian secara statistik produksi sinensetin ketiga kategori tidak menunjukkan perbedaan yang nyata (Tabel 1).

Berdasarkan hasil pengujian sinensetin per aksesi menunjukkan kadar sinensetin kontrol lebih baik dari aksesi lainnya kecuali dengan aksesi Banyumas 4 dan Jenu. Bobot kering daun per $4.41 \mathrm{~m}^{2}$ aksesi Banyumas 4, Sumbersari dan Kraksan lebih baik dari kontrol namun produksi sinensetinnya juga tidak berbeda secara statistik. Kandungan sinensetin yang ditemukan pada penelitian ini masih rendah dibandingkan penelitian terdahulu. Beberapa penelitian melaporkan kandungan sinensetin pada daun kumis kucing adalah 0.26 $0.28 \%$ (Hossain dan Salehuddin, 2009) 3.764\% (Mohamed et al., 2012), 0.13-0.32\% (Hossain dan Ismail, 2012) dan 0.311-0.567 $\mathrm{mg} \mathrm{g}^{-1}$ (Shu et al., 2016).

Berdasarkan Farmakope Herbal Indonesia (Kemenkes RI, 2009) kadar sinensetin haruslah tidak kurang dari $0.1 \%$ dalam simplia kumis kucing dan tidak kurang dari $1.1 \%$ dalam ekstrak kental daun kumis kucing. Kadar sinensetin aksesi yang diuji pada penelitian ini belum mencapai standar yang ditetapkan oleh Farmakope Herbal Indonesia. Kadar sinensetin tertinggi berdasarkan kategori bobot kering daun dan aksesi terpilih berturutturut hanya mencapai 29 dan $43 \%$ dari kadar standar yang ditetapkan.

Berdasarkan warna bunga yang dimiliki oleh aksesi tanaman kumis kucing dilakukan uji korelasi dengan kadar sinensetin yang dimiliki. Aksesi tanaman kumis kucing yang terpilih untuk diuji kadar sinensetinnya jika di kategorikan berdasarkan warna bunganya dapat dapat dilihat pada Tabel 2.

Hasil uji korelasi menunjukkan warna bunga memiliki korelasi yang kuat dengan kadar sinensetin, semakin tinggi skor (semakin ungu) warna bunga maka kadar sinensetin yang dimiliki akan tinggi pula. Tanaman kumis kucing yang memiliki warna ungu pada bunganya akan memiliki kadar sinensetin yang lebih tinggi daripada tanaman kumis kucing yang memiliki bunga berwarna putih saja. Terlihat dari rata-rata kadar sinensetin aksesi tanaman kumis kucing berbunga ungu dan intermediate lebih tinggi daripada yang berbunga putih. Hal ini juga menunjukkan warna bunga dapat dijadikan dasar pendugaan awal terhadap tanaman kumis kucing yang cenderung memiliki kadar sinensetin yang tinggi ketika ditemukan di lapangan.

\section{KESIMPULAN}

Terdapat perbedaan yang signifikan pada akumulasi pertambahan tinggi selama 8 MST, jumlah cabang sekunder, ruas cabang sekunder; panjang, lebar dan indeks luas daun; rata-rata bobot kering batang dan daun per 4.41 $\mathrm{m}^{2}$ serta kadar sinensetin antar aksesi yang diuji. Aksesi Banyumas 1, Sumbersari dan Kraksaan memiliki jumlah cabang sekunder dan ruas cabang sekunder; panjang, lebar dan indeks luas daun, rata-rata bobot kering batang dan daun per $4.41 \mathrm{~m}^{2}$ yang lebih baik daripada kontrol.

Kadar sinensetin daun berdasarkan kategori bobot kering daun mengalami peningkatan dari kategori rendah ke menengah namun menurun pada kategori tinggi. Berdasarkan perbandingan antar aksesi maupun 
kategori bobot kering daun, aksesi berbunga ungu sebagai kontrol memiliki kadar sinensetin $(0.043 \%)$ yang lebih baik, namun hanya mencapai $43 \%$ dari standar yang ditetapkan oleh Farmakope Herbal Indonesia. Tidak terdapat perbedaan yang signifikan pada produksi sinensetin aksesi yang diuji baik berdasarkan perbandingan aksesi maupun kategori aksesi.

\section{UCAPAN TERIMAKASIH}

Terimakasih kepada Direktorat Jenderal Sumber Daya Ilmu Pengetahuan, Teknologi dan Pendidikan Tinggi, Kemenristekdikti atas biaya studi program Master (BPPDN) dan Dr. Ani Kurniawati, SP, MSi yang membantu biaya penelitian dari dana penelitian Lintas Fakultas/Pusat, BOPTN 2013. Terima kasih juga kepada Pusat Studi Biofarmaka Tropika atas penyediaan sumber bahan tanam dan fasilitas pengujian di laboratorium.

\section{DAFTAR PUSTAKA}

Ameer, O.Z., I.M. Salman, M.Z. Asmawi, Z.O. Ibraheem, M.F. Yam. 2012. Orthosiphon stamineus: traditional uses, phytochemistry, pharmacology, and toxicology: a review. J. Medicin. Food. 15(8): 1-13.

Chisholm-burns, M., T. Schwinghammer, B. Wells, P. Malone, J. DiPiro. 2008. Pharmacotherapy Principles and Practice: Third Edition. McGraw-Hill.

Delima, L. Widowati, Y. Astuti, H. Siswoyo, R. Gitawati, A. Purwadianto. 2012. Gambaran praktik penggunaan jamu oleh dokter di enam provinsi di Indonesia. Buletin Penelitian Kesehatan. 40(3): 109-122.

Demura, T., H.Y. Zheng. 2010. Regulation of plant biomass production. Current Opinion in Plant Biology. 13(3): 299-304.

Hossain, M.A., S.M. Salehuddin. 2009. Simultaneous quantification of sinensetin and tetramethoxyflavone in misai kucing capsules using TLC-UV densitometric technique. J. Sci. Res. 1(2): 404-407.

Hossain, M.A., Z. Ismail. 2012. Quantification and enrichment of sinensetin in the leaves of Orthosiphon stamineus. Arabian Journal of Chemistry. 9(2): 1338-1341.

Hossain, M.A., S.M.M. Rahman. 2011. Isolation and characterisation of flavonoids from the leaves of medicinal plant Orthosiphon stamineus. Arabian Journal of Chemistry. 8: 1-4

Indariani, S., W.C. Hanny, M. Rahminiwati, W.M. Wien. 2014. Antihyperglycemic activity of functional drinks based on Java Tea (Orthosiphon aristatus) in streptozotocin induced diabetic mice. International Food Research Journal. 21(1): 349-355.

[Kemenkes RI] Keputusan Kementrian Kesehatan Republik Indonesia. 2009. Farmakope Herbal Indonesia Edisi Pertama. http://perpustakaan.depkes.go. id:8180/bitstream//123456789/3270/1/ Farmakope\%20Herbal\%20Indonesia\% 20Edisi\%20I_2008.pdf. [25 Maret 2017].

Mohamed, E.A.H., A.J. Mohamed, M.Z. Asmawi, A. Sadikun, O.S. Ebrika, M.F. Yam. 2011. Antihyperglycemic effect of Orthosiphon stamineus benth leaves extract and its bioassay-guided fractions. Molecules. 16: 3787-3801.

Mohamed, E.A.H., M.J.A. Siddiqui, L.F. Ang, A. Sadikun, S.H. Chan, S.C. Tan, M.Z. Asmawi, M.F. Yam. 2012. Potent $\alpha-$ glucosidase and $\alpha$-amylase inhibitory activities of standardized 50\% ethanolic extracts and sinensetin from Orthosiphon stamineus Benth as anti-diabetic mechanism. BMC Complementary and Alternative Medicine. 12:176.

Rahardjo, M., S.M.D Rosita. 2003. Agro ekosistem tanaman obat. Jurnal Bahan Alam Indonesia. 2(3): 89-95. 
Rahmania, R., A. Kurniawati. 2014. Penentuan ukuran stek kumis kucing (Orthosiphon aristatus Bl. Miq.) dan dosis pupuk kandang pada cara tanam langsung. J. Hort. Indonesia. 5(3): 189-202.

Samanhudi, E.S. Muliawati, E. Setyorini. 2010. Kajian frekuensi pemberian air dan macam pupuk organik terhadap pertumbuhan dan hasil tanaman kumis kucing. Jurnal Faperta Unikal. 13(8): 7085.

Sembiring, B.S., M. Rizal, S. Suhirman. 2012. Budidaya dan pasca panen kumis kucing (Orthosiphon stamineus Benth). http://pkpp.ristek.go.id/_assets/upload/d ocs/786_doc_7.pdf. [13 Juli 2014].

Setyowati, M., N. Hidayatun, Sutoro, H. Kurniawan. 2014. Evaluasi karakter morfo-fisiologis sumber daya genetik padi berumur genjah. Planta Tropika Journal of Agro Science. 2(2): 66-73.

Shu, H.G., C.T. Thing, X.N. Mei, S.C. Lee, R. Aziz, M.R. Baba, L.C. Abdullah, P.O. Sze, L.L. Chung. 2016. Study on retention of metabolites composition in misai kucing (Orthosiphon stamineus) by heat pump assisted solar drying. Journal of Food Processing and Preservation. 2017: 1-9.

Sujipto, J.P. Wahyu, Y. Widiyastuti. 2009. Pengaruh cara pengeringan terhadap perubahan fisikokimia daun kumis kucing (Orthosiphon stamineus Benth). Jurnal Tumbuhan Obat Indonesia. 2(1): 24-27.
Syukur, C. 2008. Karakterisasi tanaman kumis kucing (Orthosiphon) pada lingkungan tumbuh berbeda. Warta Penelitian dan Pengembangan Tanaman Industri. 14(3): 29-31.

Tezuka, Y., P. Stampoullis, A.H. Banskota, S. Awale, K.Q. Tran, I. Saiki, S. Kadota. 2000. Constituens of the Vietnamese medicinal plant Orthosiphon stamineus. Chem Pharm Bull. 48(11): 1711-1719.

[UPOV] International Union for The Protection of New Varieties of Plants. 2016. Draft Basil, Ocimum basilicum L. Guidelines for The Conduct of Test for Distinctnes, Uniformity and Stability. International Union for The Protection of New Varieties of Plants, Geneva, Switzerland.

Utiger, R.D. 2014. Hyperglycemia. https:// www.britannica.com/science/hyperglyc emia. [11 Juni 2017].

Wahid, P. 1998. Budidaya dan pemuliaan tanaman obat. Warta Tumbuhan Obat Indonesia. 4(1): 4-8.

Yam, M.F., E.A.L Mohammed, L.F Ang, L. Pei, Y. Darwis, R. Mahmud, M.Z. Asmawi, R. Basir, M. Ahmad. 2011. A simple isocratic HPLC method for the simultaneous determination of sinensetin, eupatorin, and 3'-hydroxy-5,6,7, 4'tetramethoxyflavone in Orthosiphon stamineus. J. Acupunct. Meridian Stud. 5(4): 176-182. 